\title{
Mining Developments, Duty to Consult and Marine Spatial Planning
}

Arctic Review on Law and Politics is pleased to present three new articles published simultaneously in February 2018. They all concern the northern sphere - the Nordic countries, Canada and the Arctic Ocean - and thus further the journal's aim to provide new academic knowledge on the North.

Gregory A. Poelzer and Thomas Ejdemo analyze resource development projects, such as mining, stating that small communities often have to make difficult decisions regarding which projects to support. The authors examine factors that contribute to the legitimacy of a new mine that opened in northern Sweden in 2012 and find that many of the factors identified in the interviews related to local outcomes and that these matched closely with economic changes associated with the mine. Given the largely positive perceptions of the mine, the balance between economic expectations and reality validate this support from the community. Therefore, the project sometimes seems too good to be true.

Christina Allard examines the rationale for the duty to consult indigenous peoples based on a comparative analysis from Nordic and Canadian legal contexts. Based on domestic legal sources, the focus of her article is to explore the legal foundation for the specific set of rules for the duty to consult. The first finding is that the rules differ among the three Nordic countries, with Sweden being the only country that lacks specific rules. Secondly, whereas Canada has developed its own duty to consult primarily through domestic case law, in the Nordic countries, duty to consult is related to international legal obligations.

Sigrid Eskeland Schütz looks at the role of marine spatial planning in the Arctic. Her starting point is that regulations of such planning in different jurisdictions is diversified and that it is difficult to claim that the international obligations of a state under UNCLOS, CBD or regional instruments, need to be fulfilled through marine spatial planning. The EU approach to marine planning is thus of particular interest. The EU members Denmark, Finland and Sweden do not have coastlines bordering the Arctic. The status of marine spatial planning in the European Arctic is thus

(C)2018 Øyvind Ravna. This is an Open Access article distributed under the terms of the Creative Commons Attribution-NonCommercial 4.0 International License (https://creativecommons.org/licenses/by-nc/4.0/), allowing third parties to share their work (copy, distribute, transmit) and to adapt it, under the condition that the authors are given credit, that the work is not used for commercial purposes, and that in the event of reuse or distribution, the terms of this license are made clear.

Citation: Øyvind Ravna. "Mining Developments, Duty to Consult and Marine Spatial Planning'Arctic Review on Law and Politics,Vol. 9, 2018, pp. 1-2. http://dx.doi.org/10.23865/arctic.v9.1158 
dependent on Norway, Greenland and Russia. The author points out that whether or not spatial planning will be used for preventive purposes in the Arctic, before the area is overwhelmed by marine activities and spatial conflicts, is uncertain.

In addition, Arctic Review is happy to present a book review written by Nigel Bankes.

Good Arctic reading!!

Øyvind Ravna

Editor-in-chief 